\title{
Integrasi Nilai-Nilai Multikultural dalam Pembelajaran PPKn di SD Fransiskus Padang Panjang
}

\author{
Ulva Huda, Rita Anggraini \\ Prodi Pendidikan Pancasila dan Kewarganegaraan \\ FIS Universitas Negeri Padang \\ E-mail: angrainirita15@gmail.com
}

\section{ABSTRAK}

Tujuan dari artikel ini yaitu untuk mendeskripsikan bagaimana pengintegrasi nilainilai multicultural dalam pembelajaran PPKn sebagai penguatan nilai toleransi di SD Fransiskus Padang Panjang. Peneiltian ini menggunakan pendekatan kualitatif dengan metode deskriptif. Informan penelitian ditentukan berdasarkan purposive sampling yang berjumlah 17 orang yang terdiri dari Kepala Sekolah SD Fransiskus Padang Panjang, Guru kelas, Siswa, dan Orang tua siswa. Data dikumpulkan selama 1 bulan melalui observasi, wawancara, dan studi dokumentasi. Selanjutnya data dianalisis berdasarkan tahapan analisis data menurut Milles dan Huberman dengan tahapan yaitu pengumpulan data, reduksi data, penyajian data, penarikan kesimpulan dan verifikasi. Hasil penelitian menunjukkan bahwa pengitegrasian nilai-nilai multicultural dalam pembelajaran PPKn yaitu melalui penanaman nilai-nilai multikultural seperti nilai pluralisme, nilai demokrasi, dan nilai humanisme. Adapun strategi yang digunakan dalam penanaman nilai-nilai multikultural tersebut yaitu metode bercerita, metode diskusi, strategi modeling, metode totor sebaya (group teaching), dan strategi pembiasaan prilaku. Dengan demikian dapat disimpulkan pengintegrasian nilai-nilai multicultural dalam pembelajaran PPKn bertujuan memberikan pemahaman kepada siswa untuk menerima, mengerti, serta menghargai setiap individu dari suku, budaya, dan nilai yang berbeda.

Kata Kunci: PPKn, nilai-nilai multikultural, toleransi

\section{ABSTRACT}

The purpose of this article is to describe how to integrate multicultural values in PPKn learning as a strengthening of the value of tolerance at SD Fransiskus Padang Panjang. This research uses a qualitative approach with descriptive methods. Research informants were determined based on purposive sampling totaling 17 people consisting of the principal of SD Fransiskus Padang Panjang, class teachers, students, and parents. Data were collected for 1 month through observation, interviews, and documentation study. Furthermore, the data were analyzed based on the stages of data analysis according to Milles and Huberman with the stages namely data collection, data reduction, data presentation, drawing conclusions and verification. The result showedthat the integration of multicultural values in PPKn learning was through the cultivation of multicultural values such as pluralism, democrazy, and humanism. The strategies used in the cultivation of these multicultural values are storytelling methods, discussion methods, modeling strategies, 
group teaching methods, and behavioral habituation strategies. Thus it can be concluded that the integration of multicultural values in PPKn learning aims to provide understanding to students to accept, understand, and respect each individual from different ethnicities, cultures, and values.

Keywords: PPKn, multicultural values, tolerance

\section{PENDAHULUAN}

Sekolah adalah salah satu sarana yang tepat untuk memberikan pemahaman mengenai keragaman budaya dan multikultural yaitu melalui pendidikan multikultural. Pendidikan multikultural merupakan suatu pendekatan progresif untuk melakukan perubahan terhadap pendidikan yang secara holistik memberikan kritik dan memperlihatkan kekurangan serta kegagalan dan juga diskriminasi yang ada dalam dunia pendidikan (Zamroni. 2011). Pemahaman mengenai keragaman ini penting dipahami oleh seluruh individu yang bertujuan untuk menghindari konflik yang terjadi ditengah masyarakat akibat dari perbedaan yang ada.

Penelitian yang dilakukan oleh Syarifudin (2018), menjelaskan bahwa peran guru PPKn dalam menanamkan nilai-nilai multikultural yaitu sebagai perancang pembelajaran, pengelola pembelajaran, dan penilai hasil pembelajaran. Sejalan dengan penelitian Bukhoiri (2018), menjelaskan bahwa nilai multikultural yang paling banyak ditanamkan adalah toleransi, tolong menolong, persamaan dan persaudaraan, serta cinta tanah air. Serta menurut Palipung (2016), menjelaskan beberapa faktor pendukung dan penghambat dalam pengimplementasian pembelajaran multikultural. Faktor pendukung diantaranya iklim sekolah, kurikulum sekolah, sarana dan prasarana, peran guru, program, dan kegiatan sekolah. Sedangkan faktor penghambatnya meliputi sikap individu dan orang tua yang masih bersikap tertutup dan kurang bisa menerima perbedaan, kurangnya media pembelajaran tentang keberagaman, kurangnya poster-poster yang menggambarkan tentang keberagaman.

Adapun perbedaan penelitian ini dengan penelitian terdahulu yaitu penulis lebih memfokuskan dalam mendeskripsikan bagaimana pengintegrasian nilai-nilai multicultural dalam pembelajaran PPKn di sekolah dasar. Sedangkan penelitian terdahulu hanya sebatas mengemukakan bagaimana peran guru PPKn dalam menanamkan nilainilai multikultural, nilai-nilai yang paling banyak ditanamkan, serta faktor pendukung dan penghambat dalam pengimplementasian pembelajaran multikultural.

SD Fransiskus merupakan salah satu lembaga pendidikan di Kota Padang Panjang yang berlatar belakang non-muslim. Sekolah ini memiliki siswa yang berasal dari 
kultur yang beragam seperti adanya perbedaan agama, suku bangsa, strata sosial, kebiasaan, dan etnis. Dari keberagaman yang ada tersebut rentan menimbulkan perselisihan antar sesama siswa di sekolah. Merujuk pada penelitian Moeis (2014) menyatakan bahwa pendidikan multikultural di sekolah belum berjalan secara maksimal. Hal ini dapat terlihat pada pelaksanaannya di sekolah hanya masih sebatas pengetahuan umum dimana guru mengembangkan multikultural pada pengenalan mengenai adanya keragaman budaya dan keharusan untuk menghormati keragaman tersebut.

Berkaitan dengan hal itu, pendidikan multikultural dapat menjadi alternatif untuk mencegah timbulnya konflik perbedaan yaitu melalui penerapan strategi dan konsep pendidikan dengan memanfaatkan keragaman yang ada di masyarakat, khususnya yang ada pada siswa, seperti keragaman agama, etnis, suku bangsa, dan kebudayaan. Dengan ini diharapkan dapat meningkatkan kesadaran siswa agar bersikap lebih humanis, pluralis, dan demokratis.

Pendidikan multikultural di sekolah bertujuan memberdayakan siswa untuk mengembangkan rasa hormat kepada orang yang berbeda budaya, memberi kesempatan untuk bekerja sama dengan orang atau kelompok yang berbeda. Pendidikan multikultural dapat dilakukan melalui pengintegrasian nilai-nilai multikultural dalam mata pelajaran PPKn. Integrasi nilai-nilai multikultural dalam pembelajaran PPKn bertujuan untuk memberikan pengetahuan dan pengalaman kepada siswa agar mereka menyadari bahwa walaupun berbeda sosial dan budayanya, namun tetap satu yaitu sebagai warga Negara Indonesia, dimana memiliki hak dan kewajiban yang sama, serta sederajat dalam Negara Kesatuan Republik Indonesia.

Berdasarkan hasil observasi awal, bentuk interaksi antar sesama siswa yang berasal dari latar belakang yang berbeda, masih ditemukan pertemanan siswa secara berkelompok dan berdasarkan strata sosial mereka. Oleh sebab itu guru berperan penting dalam menanamkan nilai-nilai keberagaman kepada peserta didik, agar tidak menimbulkan konflik dari perbedaan tersebut. Tujuan dari artikel ini adalah untuk menggambarkan bagaimana pengintegrasian nilai-nilai multikultural dalam pembelajaran PPKn di SD Fransiskus Padang Panjang. Manfaat lain yaitu dapat membantu guru mengantisipasi konflik keberagaman yang sering terjadi di sekolah, bahkan sebahagian kecil terjadi pada kalangan anak-anak. METODE PENELITIAN

Jenis penelitian yang digunakan adalah kualitatif dengan analisis deskriptif yang bertujuan untuk menggambarkan atau mendeskripsikan kondisi dan situasi yang sebenarnya yaitu bagaimana pengintegrasian nilai-nilai multikultural dalam pembelajaran PPKn di SD Fransiskus Padang Panjang (Moleong: 2012). Informan penelitian ditentukan berdasarkan purposive sampling yang berjumlah 17 orang yang terdiri dari kepala sekolah, wakil kesiswaan, guru kelas VI, siswa, serta orang tua siswa. Data 
dikumpulkan selama 1 bulan melalui wawancara, observasi, dan studi dokumentasi. Uji keabsahan data dengan menggunakan teknik trianggulasi sumber lainnya. Selanjutnya data dianalisis mengacu kepada tahapan analisis data Milles dan Huberman dengan tahapan yaitu reduksi data, penyajian data, pemeriksaan kesimpulan dan verifikasi (Sugiyono. 2005)

\section{HASIL DAN PEMBAHASAN}

\section{Pengintegrasian nilai-nilai multikultural dalam pembelajaran PPKn}

Pembelajaran multikultural merupakan strategi pendidikan yang memanfaatkan keberagaman latar belakang kebudayaan dari peserta didik sebagai salah satu kekuatan dalam membentuk sikap multikultural. Menurut Sleeter and Grant pembelajaran multikultural adalah kebijakan dalam praktik pendidikan dalam mengakui, menerima, dan menegaskan perbedaan dan persamaan yang dikaitkan dengan gender, ras, dan kelas (Retnoningsih: 2019). Pembelajaran multikultural dapat diintegrasikan pada mata pelajaran PPKn. Pemahaman mengenai keberagaman penting diajarkan kepada peserta didik terutama nilai toleransi, kebersamaan, HAM, dan saling menghargai. Berkaitan dengan hal tersebut maka pembelajaran disekolah memiliki peranan penting dalam menanamkan nilai-nilai multikultural kepada peserta didik.

Berdasarkan temuan penulis di lapangan, nilai-nilai multikultural yang ditanamkan oleh guru kepada siswa di SD Fransiskus Padang Panjang diantaranya: Pertama, nilai pluralisme yaitu penanaman nilai pluralisme oleh guru dalam pembelajaran terutama mata pelajaran PPKn, dimana guru memberikan pemahaman terkait nilai pluralisme dengan mengaitkannya dengan materi pelajaran PPKn. Adapun pluralisme itu sendiri merupakan suatu sikap saling menghargai dan menghormati setiap kebudayaan yang berbeda dan toleransi satu sama lain (Rusdiana: 2015). Penanaman nilai pluralisme kepada siswa yaitu dengan menjelaskan kenyataan akan adanya keragaman budaya kepada siswa, dimana siswa diajak oleh guru untuk menghormati setiap perbedaan yang ada dilingkungan sekitar siswa. Bentuk penanaman nilai pluralisme berdasarkan pengamatan penulis di dalam kelas VI, guru menjelaskan materi pelajaran dengan subtema Rukun Dalam Perbedaan dan tema Proklamasi, lalu guru menjelaskan kepada siswa tentang sejarah lahirnya Bangsa Indonesia, melalui materi tersebut guru menjelaskan nilai-nilai apa saja yang tersirat pada sejarah proklamsi dan mengaitkan dengan makna nilai pluralisme tersebut seperti nilai persatuan, gotong royong dan kebersamaan.

Kedua, nilai demokrasi yaitu berkaitan dengan mengubah pola pikir siswa dalam bersikap maupun bertindak yang menilai bahwa kita mempunyai hak dan kewajiban yang sama satu sama lain. Berdasarkan pengamatan penulis tentang penanaman nilai demokrasi ini yaitu, didalam proses pembelajaran, guru menanamkan kepada siswa bahwa masing-masing individu mempunyai hak dan kewajiban yang sama seperti halnya kebebasan dalam menyampaikan pendapat baik dalam 
diskusi maupun dalam proses tanya jawab. Semua siswa mempunyai kewajiban menghargai setiap perbedaan pendapat teman. Guru tidak hanya mengaitkan nilai demokrasi dalam lingkungan sekolah, namun juga di lingkungan masyarakat, seperti halnya guru menjelaskan kepada siswa bentuk hak dan kewajiban sebagai warga Negara Indonesia.

Ketiga, nilai humanisme yaitu menurut Kartika, Luciana, Yayu (2018), nilai humanisme merupakan suatu sikap yang menjunjung tinggi nilai dan martabat manusia, sehingga manusia menduduki posisi yang sangat penting diantara makhluk lain di dunia. Jadi penanaman nilai humanisme ini berkaitan dengan nilai yang menjunjung tinggi harkat dan martabat manusia. Berdasarkan pengamatan penulis didalam kelas, dimana siswa saling toleransi satu sama lain. Hal ini dapat terlihat pada saat Adzan Zuhur berkumandang dalam proses pembelajaran, seluruh siswa berhenti dari segala aktivitas yang dilakukannya. Ini merupakan salah satu bentuk toleransi siswa ditengah perbedaan yang ada. Ini dilakukan oleh seluruh siswa didalam kelas sebagai bentuk menghormati keyakinan siswa yang muslim, walaupun didalam kelas tidak semua siswa muslim.

Melalui penanaman nilai-nilai multikultural atau keberagaman, guru menggunakan beberapa metode dan strategi dalam penyampaiannya kepada siswa. Hal ini bertujuan agar nilai-nilai yang disampaikan dapat diterima dan dijalankan oleh siswa baik di lingkungan sekolah maupun lingkungan sekitarnya dengan benar. Adapun metode atau strategi yang digunakan adalah: Pertama, metode bercerita dimana metode ini dapat dijadikan sebagai cara dalam menanamkan nilai-nilai yang berlaku dalam masyarakat. Berdasarkan pengamatan penulis, dimana guru menceritakan sebuah cerita yang berkaitan dengan materi pelajaran, lalu guru mengaitkan nilai-nilai tentang keragaman dan multikultural tersebut kedalam cerita sebagai nilai moral yang dapat menjadi pedoman bagi siswa dalam berinteraksi dengan antar sesama ditengah keberagaman.

Kedua, metode diskusi dimana metode diskusi ini lebih menekankan dalam penanaman nilai-nilai menghargai pendapat teman, kerjasama, gotong royong, kekeluargaan, dan persatuan. Berdasarkan pengamatan penulis pada saat proses pembelajaran dengan metode diskusi, guru selalu mengelompokkan siswa dari berbagai latar belakang yang berbeda, baik keyakinan, etnis, maupun suku bangsa dengan tujuan agar siswa mampu bekerjasama tanpa memandang perbedaan yang ada. Serta melalui metode diskusi ini siswa dapat dibentuk oleh guru, untuk lebih menghargai pendapat teman yang lainnya dan tidak saling merendahkan.

Ketiga, strategi modeling dimana guru harus mampu menjadi teladan bagi siswa. Berdasarkan pengamatan penulis di SD Fransiskus juga mempunyai guru yang berasal dari latar belakang yang berbeda. Hal ini dapat menjadi contoh bagi siswa tentang bagaimana interaksi antar guru yang juga beragam, serta bentuk toleransi antar masing-masing guru dalam merayakan hari besar keagamaan. Menurut Bukhori (2018) 
Guru yang ideal adalah mereka yang mampu menempatkan posisinya sebagai fasilitator, pemimpin, orang tua, bahkan tempat menyandarkan kepercayaan dan membantu orang lain.

Keempat, metode tutor sebaya (group teaching) dimana metode ini cukup efektif untuk meningkatkan interaksi sosial antar sesama siswa ditengah keberagamannya, mereka tidak memandang perbedaan yang ada dalam berbagi ilmu yang mereka miliki, tanpa diskriminasi dan melihat latar belakang temannya. Kelima, strategi pembasaan prilaku yaitu pembiasaan yang dilakukan kepada siswa selama proses pembelajaran. Seperti halnya berbaris didepan kelas dan bersalaman dengan guru sebelum masuk kelas, berdoa sebelum dan sesudah belajar sesuai keyakinan masing-masing, mengangkat tangan jika ada yang bertanya atau menyampaikan pendapat.

\section{KESIMPULAN}

Berdasarkan hasil penelitian dan pembahasan yang telah dilakukan dapat disimpulkan bahwa pengintegrasian nilai-nilai multikultural dalam pembelajaran PPKn di SD Fransiskus Padang Panjang dilakukan melalui penanaman nilai-nilai inti multikultural seperti nilai pluralisme, nilai demokrasi, dan nilai humanisme. Penanaman nilai-nilai tersebut dilakukan dengan mengaitkan nilainilai tersebut kedalam materi pelajaran terutama mata pelajaran PPKn. Adapun guru mengggunakan berbagai macam metode/strategi yang digunakan dalam penanaman nilai-nilai multikultural tersebut kepada siswa, seperti metode bercerita, metode diskusi, strategi modeling, metode tutor sebaya (teaching group), dan strategi pembiasaan prilaku yang dilakukan oleh guru kepada siswa. Berdasarkan hasil wawancara penulis bahwa metode yang efektif digunakan dalam penanaman nilai-nilai multikultural kepada siswa yaitu metode bercerita dan strategi pembiasaan prilaku.

\section{DAFTAR PUSTAKA}

Bukhori, I. (2018). Metode

Penanaman Nilai-Nilai

Multikultural Pada Siswa Kelas

Rendah (Studi Pada Mi Di

Mwcnu Lp. Maarif Kraksaan).

Edureligia; Jurnal Pendidikan

Agama Islam, 2(1), 41-52.

https://doi.org/10.33650/edure

ligia.v2i1.756

Kartikawati, D., Radjagukguk, D. L., \& Sriwartini, Y. (2018).

Penanaman Nilai-Nilai

Multikultural Melalui

Komunikasi Pendidikan Di

Sekolah Dasar Inklusi Di

Yogyakarta Dan Surakarta.

Widya Komunika, 8(2), 58.

https://doi.org/10.20884/wk.v8

i2.1406

Kewaraganegaraan, J. P., \& Volume, H. (2018). Jurnal Pndidikan Kewaraganegaraan dan Hukum Volume 7 No 2 Tahun 2018. 7(2), 390-398.

Palipung, N. (2016). Implementasi Pendidikan Multikultural Di Sekolah Inklusi Sd Taman Muda Ibu Pawiyatan Tamansiswa Yogyakarta. Jurnal Kebijakan Publik, $V$, 558-566.

Sugiyono. 2005. Memahami Penelitian Kualitatif, Bandung: CV. Alfabeta Suryana Yaya, Rusdiana. 2015. Pendidikan Multikultural Suatu Upaya Penguatan Jati Diri Bangsa. Bandung. Pustaka Setia 
Syah, Muhibbin. 2002. Psikologi Belajar. Jakarta:PT. Raja Grafindo Persada

Wiroatmojo dan Sasonoharjo. 2002. Media Pembelajaran. Jakarta: LAN RI

Zamroni. 2011. Pendidikan Demokrasi pada Masyarakat Multikultural.
Yogyakarta:Gavin Kalam Utama

Irwan, I., Indrawadi, J., \& Waldi, A. (2018). Urgensi Internalisasi Nilai-nilai Ketahanan Nasional dalam Pembelajaran PPKn Tingkat SMP (Studi di Kabupaten Solok Selatan. Journal of Civic Education,1(1), 1-8. 